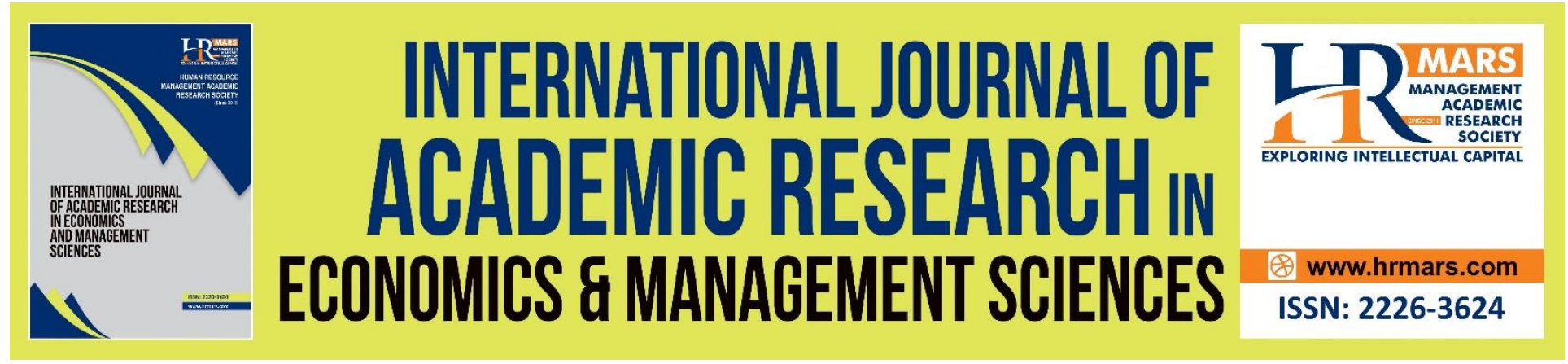

\title{
Agriculture Production, Pollution Emissions and Economic Growth from Southeast Asian Perspective
}

Shairil Izwan Taasim, Adrian Daud, Anita Rosli

To Link this Article: http://dx.doi.org/10.6007/IJAREMS/v10-i3/10163

DOI:10.6007/IJAREMS/v10-i3/10163

Received: 01 May 2021, Revised: 25 May 2021, Accepted: 09 June 2021

Published Online: 08 July 2021

In-Text Citation: (Taasim et al., 2021)

To Cite this Article: Taasim, S. I., Daud, A., \& Rosli, A. (2021). Agriculture Production, Pollution Emissions and Economic Growth from Southeast Asian Perspective. International Journal of Academic Research in Economics and Managment and Sciences, 10(3), 31-43.

Copyright: (C) 2021 The Author(s)

Published by Human Resource Management Academic Research Society (www.hrmars.com)

This article is published under the Creative Commons Attribution (CC BY 4.0) license. Anyone may reproduce, distribute, translate and create derivative works of this article (for both commercial and non-commercial purposes), subject to full attribution to the original publication and authors. The full terms of this license may be seen at: http://creativecommons.org/licences/by/4.0/legalcode

Vol. 10, No. 3, 2021, Pg. 31 - 43

http://hrmars.com/index.php/pages/detail/IJAREMS

JOURNAL HOMEPAGE

Full Terms \& Conditions of access and use can be found at http://hrmars.com/index.php/pages/detail/publication-ethics 


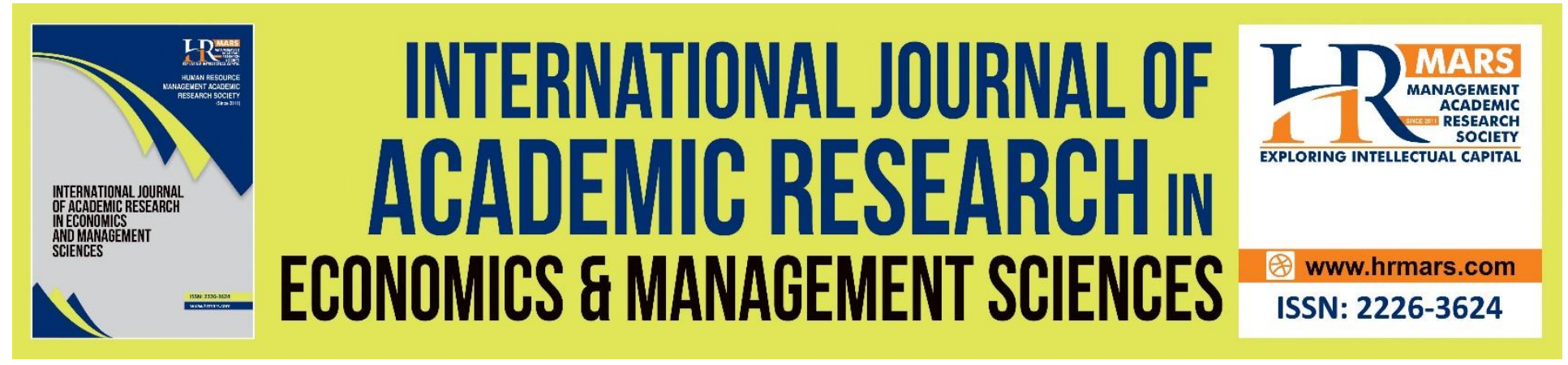

\title{
Agriculture Production, Pollution Emissions and Economic Growth from Southeast Asian Perspective
}

\author{
Shairil Izwan Taasim, Adrian Daud, Anita Rosli \\ Department of Social Science and Management Faculty of Humanities, Management and \\ Science Universiti Putra Malaysia Kampus Bintulu \\ Email: shairil@upm.edu.my
}

\begin{abstract}
The rapid increase in population worldwide is causing large scale of production of agricultural products and increased preparation of plants, livestock, vegetables and much more agricultural items for people's use and food security. The implications from this is that, South East Asian, especially, invests in technology for large scale production for a sustainable environment. By applying the panel data analysis technique Fully Modified OLS and Dynamic OLS, this paper investigates the causal relationship between agricultural production, pollution emissions and Gross Domestic Product (GDP) among, South East Asian countries. The paper results show the variable has a long-run and short-run relationship with a positive value. While in a developing country, investment in an agricultural product based on sustainable agriculture that meets present food requirements without affecting the environment should be considered as an alternative for the benefit of future generations.
\end{abstract}

Keywords: Agriculture, Panel Data, South East Asian, Sustainability.

\section{Introduction}

In the early time period, agricultural product was the dominant sector for most, South East Asian countries. Its decline has been due to the industrial revolution in the 1970s or manufacturing and, since the year 2000, a revolution in technology. Nowadays, agriculture has changed to commercial products due to fulfilling worldwide demand. The increasing population has affected the demand for livestock, farming, forestry fisheries and other agricultural products. Most, South East Asian countries implemented technology in agriculture products to increase production. Pacheco, Ochoa, Ordonez and Izquierdo (2018) mentioned that for agriculture to develop and reach its full potential, this would require several favourable conditions; one of them is the technological change that contributes to improving productivity. In additional one of agricultural production contribution according to Franić and Mikuš (2013) opportunities of farm in increase 
income and added value through organic production, traditional practices or new products development.

Cultivation of exotic vegetables, as an example, despoils the environment and has an impact on pollution. Fei (2018) said that the severity of agricultural pollution has surpassed industrial and urban discharges and has been one of China's major sources of atmospheric, water and soil pollution. Chart 1 shows the trend of annual Gross Domestic Product (GDP) for selected, South East Asian countries. Singapore was one of a high-income country showing a trend for GDP of less than 6\% since 2011 and other Southeast Asian countries also had annual growth of less than 6\%, excluding the Philippines and Vietnam which both had more than $7 \%$. To maximize profit for countries and with huge demand for agricultural products, South East Asian countries invest and dominate agricultural production as a top priority.

Chart 1: GDP growth (annual \%)

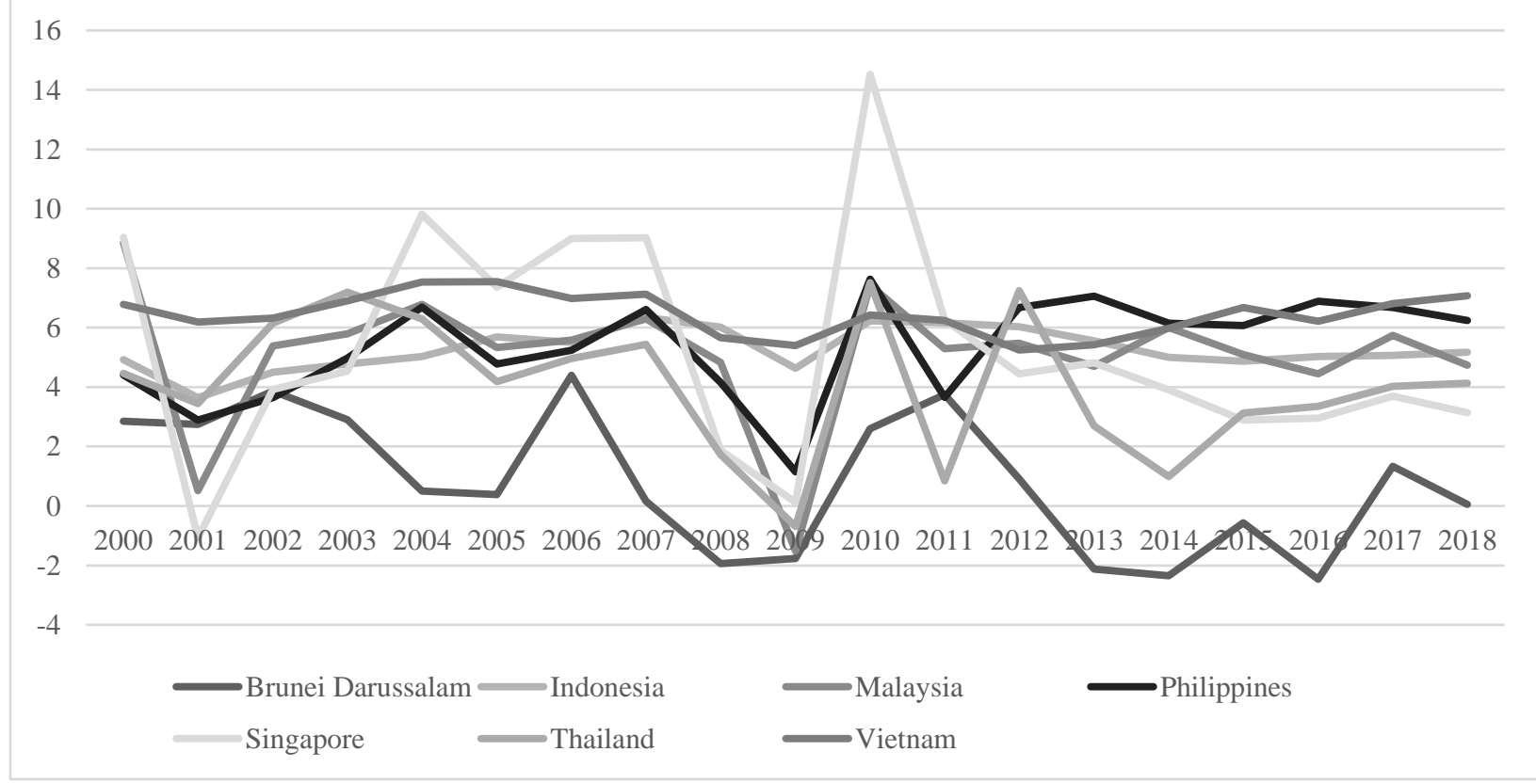

Source: World Bank, 2019

Agricultural related pollution control is of a global issue, especially with a discussion regarding sustainable development. According to Fei (2018) the prevention and control of agricultural pollution and the development of agricultural ecologicalisation are a systematic project and require tangible efforts from governments, entrepreneurs, and farmers and NGOs. Ozgur, Ilker and Lewell (2012) wrote that agricultural development may be of special importance in reducing poverty in developing countries, partly due to the prevalence of poverty in rural areas of those countries. However, according to Xiao et al (2021) the agricultural and industrial sectors are major sources of water pollution in developing countries. Although the agricultural was vital for global trading today and has grown due to high demand.

Consideration is given to economic development as the main driver to increasing GDP for, South East Asian and agricultural production is an essential factor. The multiplier effect from bidirectional causality between each other, especially the impact of pollution, should be 
considered to achieve sustainable development. We aim to answer the relationship between agricultural growth (represented by agricultural production) to pollution and income for ASEAN using the panel cointegration technique, which is Fully Modified OLS (FMOLS) and Dynamic OLS (DOLS). Payam, Tamat and Fathin (2018) noted that DOLS and FMOLS are superior to the OLS for many reasons. OLS estimates are super-consistent, but the t-statistic was acheved without stationary or I(0) terms, which are only approximately normal. We selected the, South East Asian countries which were involved in this research: Brunei, Indonesia, Malaysia, Philippines, Singapore, Thailand and Vietnam.

\section{Literature Review}

The existing literature on the relationship between economic growth and agricultural sector is mostly related in the world because this sector was foundation income in the beginning of national economic especially in Asian. One of study was conducted by Ozgur (2012) examined the impact of agricultural aid on per-capita income for 66 countries. They used a multiple estimator and model specification and found a positive relationship between agricultural aid and economic growth. According to Raza, Ali and Mehboob (2012), agriculture contributes a significant impact on the economic growth of Pakistan. The study used time series data with descriptive analysis. They suggested to the government to concentrate on the development of the agriculture sector. This sector comprises the backbone of the economy.

The research for economic performance in an underdeveloped country was conducted in Iraq, a country facing a restricted source of economics and depending on agriculture. A study by Alattabi, Albadri and albadawi (2019) investigated the causal relationship between agricultural exports and agricultural growth for the period 1990-2017 using Vector Auto-regressive (VAR). The research was conducted in Iraq because sanctions were imposed by the United Nations and ariculture was a source of income for rural areas. They found no causal relationship from any direction between agricultural exports and agricultural growth in Iraq, and this result shows that Iraq was still suffering from economic disruption from sanctions imposed by the United Nations.

Thailand is one of agriculture's main player since long ago and it is the key factor for their import sector. A study by Jatuporn et al (2014) found long-term stability detected in a bidirectional relationship running from agriculture to economic growth and from economic growth to agriculture. The study was implied by Vector Autoregressive (VAR) as a method with diagnosis by the Wald test and Granger causality for the time series data. An additional study in Indonesia by Pingali (2010) showed that the factor industrialisation has caused added value and has growth beyond the growth rate after a transformation in the manufacturing industry which has emerged as a dominant contributor and given the impact to agriculture sector.

This sector which have led to polarization and dualism to industry strategies which depend on capital accumulation, protection and high technology. According to Xiao et al (2021) different sectors, such as the agricultural sector, the industrial sector, and the service sector, have different environmental policies that lead to different environmental behaviors

Nowdays, agricultural production changes transformations with the world current situation which is green economy to maintain and sustain ecology system. The numbers of limited for land and increasing demand for agricultural product, the technology and agricultural were hybrid. However, it also has brought various unneglectable environmental consequences which the serious environmental pollution, and the imbalanced ecosystem (Chen et al., 2017; Shenet 
al., 2018). The path of technological innovation is the way by which economic growth can accelerate agricultural production. Although the implication according to Fei (2018), is that agricultural pollution is increasingly becoming one of the most significant and prominent environmental problems, while Chinese small-scale farmers' production patterns make the agriculture pollution control a difficult problem. Awokuse (2009) showed that the agricultural sector could play a role as an engine of growth in selected Africa, Asia and Latin America countries. A study also was conducted by Rasool, Malik and Tarique (2020), revisiting the evidenced a long-run and short-run relationship in India among $\mathrm{CO}_{2}$, energy consumption, economic growth, the square of economic growth and financial development. They found evidence for sample period 1971-2014, a long-run and short-run relationship using the ARDL Bound test as methodology of research.

One of method to measure impact environment towards economic was using Environemntal Kuznets Curve (EKC). The study by Egbetokun et al (2019) from EKC methods, environmental quality and economic growth does not effected to environmental pollution. In additional, the author also mention population growth does not effect to level of consume carbon resources among Nigerian. However, the study among European Union was conducted by Zafeiriou et al. (2018) using NARDL cointegration test relationship between per capita income and agricultural emissions was positive. The study by Dar \& Asif (2019) agricultural contribution were led to increasing environmental quality in the long term. The analysis was using Granger causality tests and results to confirm bidirectional causality between income and carbon emissions among South Asian Association for Regional Cooperation.

\section{Agricultural and South East Asian}

Mainstream source of economic growth among, South East Asian in an early independent were from agricultural production. In increasing number of population and higher of number poverty, agricultural as a vital development tool (Dao, 2009). In additional, the crisis in economic given the impact to Southeast Asean especially as small economy. This led to increasing poverty and according to Ravallion and Chen (2007), agriculture growth contributed more towards reducing poverty than either industry or services. Chart 2 presents the food production index from Southeast Asian countries. The trend for production index increases over time for this region, especially Vietnam. In 2005, food index for South East Asian countries reached more than 100. Promotion and investment from agriculture production would be one of contribution towards economic growth for countries. The study Franić and Mikuš (2013) production capacities in the main part of agriculture make it the granary for Croatia, excellent result being achieved in the winegrowing and winemaking industry. The chances and opportunity in South East Asian, would be value added because the land, geographical instruments, and natural resource is makes it possible producer in agricultural. 
INTERNATIONAL JOURNAL OF ACADEMIC RESEARCH ECONOMICS AND MANAGEMENT SCIENCES Vol. 10, No. 3, 2021, E-ISSN: 2226-3624 ㄷ 2021 HRMARS

Chart 2: Food production index

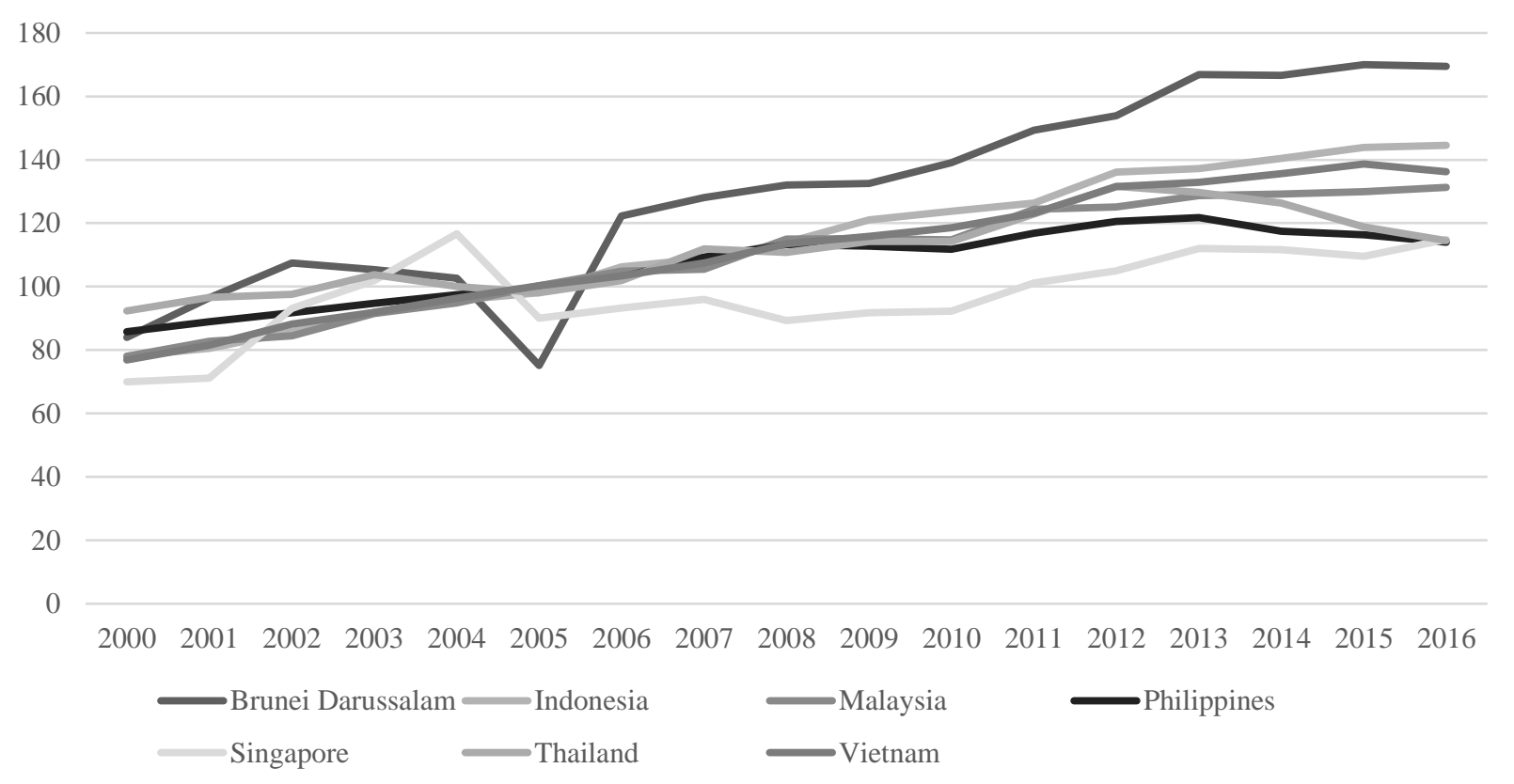

Source: Food and Agriculture Organization, 2019, UN

The security food is greatly vulnarble if among South East Asian would not focus to develop agriculture and still depend as importers. The agriculture has a source of income for most rural communities (Chandio et al., 2020; Husnain et al., 2018) and to ensure food security countries would be adapt technology to agriclutral to boost production. Although according to Regmi and Weber (2000) most of developed countries would rather deal with farming crises triggered by overproduction, whereas many developed countries are struggling to ensure that food output takes precedence over population growth. Some of previous study was discussed in literature section indicated that potential boost in agricultural production have a problem to environmental because the issue of climate change on agriculture. This study would suggest and identify the opportunity from agricultural industry in the South East Asian towards economic growth and implication to pollution.

Numerous study were positive implication from increasing agricultural producing was led to emissions. To decreasing this issue, government intervention would be indicator to take measures aiming to limit resource use (Zafeiriou et al., 2018). Li, Gong and Yang (2019) said the promotion of agricultural economy may bring agricultural pollution, and agricultural pollution may restrain the development of the agricultural economy. According to Botri (2013), by including agriculture sector the impact on economic growth is useful for developing endogenous growth theories. The relationship between them has an impact on the development of agriculture and public health. This research paper is beneficial to identify the implications of agricultural production for income and pollution. 


\section{Methodology}

The model specification is to investigate the relationship of agricultural production, South East Asian to pollution emissions and economic growth. We developed a framework where the relationship can be specified as follows:-

$\log (\mathrm{agr})_{\mathrm{it}}=\alpha+\mathrm{v}_{\mathrm{i}} \log (\mathrm{Ly})_{\mathrm{it}}+\mathrm{v}_{\mathrm{i}} \log (\mathrm{LCO} 2)_{\mathrm{it}}+\mu_{\mathrm{it}}$.

Where lagr, Ly and Lco2 represent natural logarithms of agricultural yearly revenue, real income and pollution emissions (as the proxy level of pollution). where $i=1,2, \ldots, \mathrm{F}$ and $t=1,2, \ldots \mathrm{T}$ are country and time notations. A dataset obtained from World Bank Database for ASEAN countries., South East Asian countries for this analysis were Brunei, Indonesia, Malaysia, Philippines, Singapore, Thailand and Vietnam. We eliminated Laos PDR, Cambodia and East Timor from our analysis because of the restricted source of data. Variable $\mu_{\text {it }}$ is the country-specific fixed effect; it helps the analysis to be stable over time even with other factors. In term of predication model, estimation and diagnostic checking to identify data to ensure valid and like our model and theory.

Before we analyse the short and long-run relationship for our model, the data should stationary at the same order to produce the FMOLS and DOLS test. A panel unit root test and panel cointegration test is performed. There are several unit root tests that can perform a panel unit root test. Firstly, we perform Augmented Dickey Fuller-Fisher (ADF) and Phillips-Perron (PP) to identify stationary. According to Shairilizwan and Remali (2014), the aim of conducting these tests is to ensure that the chosen variables are not I(2) so as to avoid bias in the estimation. Secondly, test Levin, Lin and Chu (2002) or LLC and Im, Pesaran and Shin (2003) or IPS are two methods that can be used to test data stationarity for panel data for cointegration. The difference LLC test and IPS assume parameters are constant across all cross-section and IPS varies freely across the cross-section. IPS and Augmented Dickey Fuller-Fisher (ADF-test) assume individual unit root processes.

Panel FMOLS and DOLS tests were carried out next to estimate variable. According to Harris and Sorris (2003), FMOLS is a non-parametric to cope with correlation for serial correlation and DOLS is a parametric approach where lagged first differenced terms are clearly estimated. Liddle (2012) FMOLS estimator is a mean or between group estimator that allows for a high degree of heterogeneity in the panel. From equation modelling (1) $\alpha$ denotes country-specific effects and $v_{i}$ is the deterministic time trends and $\mu$ is the residual. For Fully Modified Ordinary Least Square (FMOLS) considers the following cointegrated system for a panel of $i=1,2, \ldots . . \mathrm{N}$ individuals and $t$ stand for the time period.

It is also assumed that $\vartheta_{i t}=\lim T \rightarrow \infty E\left[T^{-1}\left(\sum_{t=1}^{T} v_{l i T}\right)\left(\sum_{t=0}^{T} v_{l i T}\right)\right]$ is the covariance vector and decomposed into $\vartheta_{i t}=\vartheta_{i t}+\Gamma_{i}+\Gamma_{i}^{\prime}$ where it is the contemporaneous covariance and $\Gamma_{i}$ is a weighted sum of autocovariances. The FMOLS estimator can be estimated as follows:

$\beta_{\text {fmols }}^{*}=N^{-1} \sum_{1}^{N}\left(\sum_{t=1}^{T}(L y-\overline{L y})^{2}\left(\sum_{t=1}^{T}(L y-\overline{L y}) a g r_{i t}^{*}-T_{\hat{\tau}_{i}}\right.\right.$

Where the DOLS estimator is estimated:

$\beta_{\text {dols }}^{*}=N^{-1} N^{-1}\left(\sum_{i=1}^{N} Z_{i t} Z_{i t}^{\prime}\right)^{-1}\left(\sum_{i=1}^{N} Z_{i t} a g r_{i t}^{*}\right)$

(3)

Where $Z_{i t}=\left(X_{i t}-\bar{X}_{i}, \Delta X_{i, t-k}, \ldots, \Delta X_{i, t+k}\right)$ is $2(K+1) \times 1$ vector of the regressor. 
According to Dursun and Ogunleye (2016) DOLS and FMOLS estimator showed deviated results when it was estimated by least-squares method. Kao and Chaing (2000) DOLS had a smaller bias of the independent variables and can minimize in degree of freedom.

\section{Estimation Results}

Before analysing the long-run relationship, we examined the unit root test as discussed in the methodology section. Table 3 shows the result from our analysis unit root test using LLC and IPS method. We can conclude all variables are stationary at the $1^{\text {st }}$ difference. So we can suggest all the variables are integrated at order one I(1). This unit root test is allowed to analyse the next steps of co-integration, Pedroni (1999) and Kao's (1999), to check whether there is a cointegration equation among our variables. Im et al (2003) IPS test allows a heterogeneous autoregressive unit root process across cross-section. According to Pesaran (2007) when cross sectional dependence is high, the first generation tests tend to over-reject the null. All this test assumes the null hypothesis is nonstationary to allow same order of magnidute.

Table 3: Panel unit root test

\begin{tabular}{|c|c|c|c|c|c|c|c|c|}
\hline & \multicolumn{4}{|l|}{ At level } & \multicolumn{4}{|c|}{ At $1^{\text {st }}$ difference } \\
\hline & $\begin{array}{l}\text { Without } \\
\text { trend }\end{array}$ & p-value & $\begin{array}{l}\text { With } \\
\text { trend }\end{array}$ & p-value & $\begin{array}{l}\text { Without } \\
\text { trend }\end{array}$ & $\begin{array}{l}p- \\
\text { value }\end{array}$ & $\begin{array}{l}\text { With } \\
\text { trend }\end{array}$ & $\begin{array}{l}\text { p- } \\
\text { value }\end{array}$ \\
\hline $\begin{array}{l}\text { LLC } \\
\text { dagr } r_{t} \\
\text { dlyt } \\
\text { dco2 }{ }_{t}\end{array}$ & $\begin{array}{l}-2.54 \\
-0.96 \\
-4.13\end{array}$ & $\begin{array}{l}0.01 * \\
0.17 \\
0.00 *\end{array}$ & $\begin{array}{l}-1.88 \\
-1.56 \\
-2.37\end{array}$ & $\begin{array}{l}0.03 * \\
0.06 \\
0.00 *\end{array}$ & $\begin{array}{l}-11.00 \\
-12.46 \\
-12.55\end{array}$ & $\begin{array}{l}0.00 * \\
0.00 * \\
0.00 *\end{array}$ & $\begin{array}{l}-9.18 \\
-10.15 \\
-10.76\end{array}$ & $\begin{array}{l}0.00 * \\
0.00 * \\
0.00 *\end{array}$ \\
\hline $\begin{array}{l}\text { IPS } \\
\text { dagr } r_{t} \\
\text { dlyt } \\
\text { dco2t }\end{array}$ & $\begin{array}{l}-0.77 \\
1.94 \\
-1.68\end{array}$ & $\begin{array}{l}0.22 \\
0.97 \\
0.05\end{array}$ & $\begin{array}{l}0.08 \\
-0.77 \\
-1.45\end{array}$ & $\begin{array}{l}0.53 \\
0.22 \\
0.07\end{array}$ & $\begin{array}{l}-13.09 \\
-13.54 \\
-14.75\end{array}$ & $\begin{array}{l}0.0 *^{*} \\
0.00^{*} \\
0.00 *\end{array}$ & $\begin{array}{l}-11.74 \\
-12.00 \\
-13.58\end{array}$ & $\begin{array}{l}0.00 * \\
0.00 * \\
0.00 *\end{array}$ \\
\hline
\end{tabular}

Note: dag $_{\mathrm{t}}$ is the Agricultural Production while $d \mathrm{dl}_{\mathrm{t}}$ and $\mathrm{dco} \mathrm{2}_{\mathrm{t}}$ are the real income and pollution emissions, respectively. P-Value $<0.05(* *),<0.01(*)$ indicates the rejection of null hypothesis of no cointegration at $10 \%, 5 \%$, and $1 \%$ levels of significance, respectively.

If the test have a problem of heteriscedasticity and autocorrelation, the following steps purpose by (Maddala and $\mathrm{Wu}, 1999)$ which is subtract cross-section averages from the data to eliminate the influence of aggregate effects of apply the Augmented Dicket-Fuller (ADF) to test each variable. Since the model based on the single equation, Pedroni $(1999,2004)$ was used. Table 4 reports the cointegration analysis from our model. The analysis outcome is 6 out of 8 statistics in cointegration are significant at the level of $1 \%$. Pedroni (1999) says cointegration there are seven test statistics, four within dimension-based statistics and the rest between dimension statistics. From our analysis, group between dimension is significant at level $1 \%$ and panel within dimension onlen Panel V-statistic is not significant but the rest is significant at $1 \%$. For additional cointegration tests, Kao (1999) analysis not significant. 
INTERNATIONAL JOURNAL OF ACADEMIC RESEARCH ECONOMICS AND MANAGEMENT SCIENCES Vol. 10, No. 3, 2021, E-ISSN: 2226-3624 @ 2021 HRMARS

Table 4: Pedroni's (1999) and Kao's (1999) panel cointegration tests

\begin{tabular}{|l|l|l|l|l|l|l|l|l|}
\hline Test & $\begin{array}{l}\text { Panel v- } \\
\text { statistic }\end{array}$ & $\begin{array}{l}\text { Panel } \\
\text { rho- } \\
\text { Statistic }\end{array}$ & $\begin{array}{l}\text { Panel } \\
\text { PP- } \\
\text { Statistic }\end{array}$ & $\begin{array}{l}\text { Panel } \\
\text { ADF- } \\
\text { Statistic }\end{array}$ & $\begin{array}{l}\text { Group } \\
\text { rho- } \\
\text { Statistic }\end{array}$ & $\begin{array}{l}\text { Group } \\
\text { PP- } \\
\text { Statistic }\end{array}$ & $\begin{array}{l}\text { Group } \\
\text { ADF- } \\
\text { Statistic }\end{array}$ & $\begin{array}{l}\text { Kao } \\
\text { Test }\end{array}$ \\
\hline Statistic & -1.35 & -6.75 & -11.34 & -6.61 & -5.21 & -13.12 & -5.19 & -0.18 \\
& $(0.92)$ & $(0.00)^{*}$ & $(0.00)^{*}$ & $(0.00)^{*}$ & $(0.00)^{*}$ & $(0.00)^{*}$ & $(0.00)^{*}$ & $(0.43)$ \\
\hline
\end{tabular}

Note: P-values are shown in parentheses. All reported values are asymptotically normally distributed. Probability statistics, shown within parentheses. ${ }^{*}, * *, * * *$ indicate the rejection of the null hypothesis of no cointegration at $10 \%(* * *), 5 \%\left({ }^{* *}\right)$, and $1 \%\left({ }^{*}\right)$ levels of significance, respectively.

Panel v-statistic, Panel rho-Statistic, Panel PP-Statistic, Panel ADF-Statistic are four dimensions, which are one simple panel cointegration to ADF-test, and the rest are based on a group mean. The results between dimensions show that the null hypothesis of no cointegration can be rejected in most cases. From our reported co-integration analysis, we can conclude the existence of a long-term relationship in our model which we can perform to estimate FMOLS and DOLS model. Furthermore, the ADF statistics perform better if the errors follow an autoregressive process (Harris and Sollis, 2003).

Table 5: FMOLS and DOLS panel

\begin{tabular}{|l|l|l|l|l|}
\hline \multirow{2}{*}{ Variable } & \multicolumn{2}{|l|}{ FMOLS } & DOLS \\
\cline { 2 - 5 } & Coefficient & P-value & Coefficient & P-value \\
\hline Real Income $\left(\mathrm{Y}_{\mathrm{t}}\right)$ & 0.122 & $0.00^{*}$ & 0.115 & $0.09 * * *$ \\
\hline $\begin{array}{l}\text { Pollution emissions } \\
\left(\mathrm{CO}_{\mathrm{t}}\right)\end{array}$ & 0.067 & $0.06^{* * *}$ & 0.229 & $0.02^{* *}$ \\
\hline
\end{tabular}

Note: Agricultural Production Revenue is treated as the dependent variable. $\mathrm{Y}_{\mathrm{t}}$ and $\mathrm{CO}_{\mathrm{t}}$ are countries' real income and pollution emissions rate, respectively. P-Value $<0.10(* * *),<$ $0.05(* *),<0.01(*)(n t)$ are not significant, indicating the rejection of null hypothesis of no cointegration at $10 \%, 5 \%$, and $1 \%$ levels of significance, respectively.

Once a cointegrations relationship is done, the panel FMOLS and DOLS technique is implied rather than Pooled Least Square (PLS) technique, because PLS will lead to biased estimations which is the result of a serial correlation problem. Both models have significant and positive effects on revenue from agricultural production in the long-run as shown in Table 5. If the, South East Asian countries lead to increased agricultural production to gain revenue for them, the sign for results \% increase in agricultural production income leads to an increase of $1.2 \%$ of real income and will lead to an impact of $0.6 \%$ pollution emissions for, South East Asian for FMOLS technique. For DOLS technique, it is a significant and positive effect which is an increase of $1 \%$ in agricultural production revenue implying an increase of $1.15 \%$ real income for ASEAN and $2.29 \%$ effect on pollution emissions. 
Table 6: Panel Causality Results

\begin{tabular}{|l|l|l|}
\hline Method & Wald Test & Prob \\
\hline FMOLS Model & 14.77 & 0.00 \\
\hline DOLS Model & 7.17 & 0.00 \\
\hline
\end{tabular}

We also applied the Wald-Test panel causality to test and detect the relationship of causality between agricultural production revenue, real income and pollution emissions in the short run. Table 6 shows that the null hypothesis is rejected at $5 \%$ and concludes that real income and pollution emissions do not cause agricultural production for both techniques. We can imply a variation in real income, and pollution emissions significantly lead to changes in the agricultural industry.

\section{Conclusion}

This study was conducted to examine, South East Asian agricultural production link between real income and pollution emissions $\left(\mathrm{CO}_{2}\right)$ over the period 2000-2014. The empirical results from FMOLS and DOLS technique reveal that there is a positive relationship in the long run and short run. In this study, since pollution emission is a positive relationship with the agricultural industry, it suggests that strengthens the need to monitor pollution in this industry. The implication for large-scale agriculture production from this study was a positive relationship with pollution emissions. The findings provide an opportunity to give a policy marker in investment into agricultural sustainability to produce more to environment friendly. Addition info from a study by Yip, Brooks, Do and Nguyen (2020) showed that agricultural production techniques are more energy-intensive in comparison with the majority of other sectors. Sun et al. (2012) although many techniques and integrated resource management practices that can mitigate the adverse effects of intensive farming on the environment. Thus, an increase in oil prices may cause a surge in agricultural commodity prices due to higher production costs through its impacts on fertiliser, transportation costs and other input prices. South East Asian as disscuion in literature section have a comparative advantage then other region in the world if focusing in agriculture. The geographical is strength for this region and fertile soil was advantages.

\section{Reference}

Awokuse, T. O. (2009). Does Agriculture Really Matter for Economic Growth in Developing Countries? Paper presented at the American Agricultural Economics Association Annual Meeting, Milwaukee, WI, July 26-28. Retrieved from http://ageconsearch.umn.edu/bitstream/49762/2/AAEA2009_Submission_Ag_Led_Gro wth_050109.pdf

Botri, V. (2013). Determinants of Intra-industry Trade between Western Balkans and EU15: Evidence from Bilateral Data. International Journal of Economic Sciences and Applied Research, 6(2), 7-23.

Harris, R., \& Sollis, R. (2003). Applied time series modelling and forecasting. Chichester: John Wiley and Sons.

Chen, W., Chen, J., Xu, D., Liu, J., \& Niu, N. (2017). Assessment of the practices and contributions of China's green industry to the socio-economic development. Journal of Cleaner Production, 153, 648-656. https://doi.org/10.1016/j.jclepro.2016.11.065 
Chandio, A. A., Jiang, Y., Rehman, A., \& Rauf, A. (2020). Short and long-run impacts of climate change on agriculture: an empirical evidence from China. International Journal of Climate Change Strategies and Management, 12(2), 201-221. https://doi.org/10.1108/ijccsm-052019-0026

Dar, J. A., \& Asif, M. (2019). Do agriculture-based economies mitigate CO2 emissions? International Journal of Energy Sector Management, 14(3), 638-652. https://doi.org/10.1108/ijesm-01-2019-0011.

Egbetokun, S., Osabuohien, E., Akinbobola, T., Onanuga, O. T., Gershon, O., \& Okafor, V. (2020). Environmental pollution, economic growth and institutional quality: exploring the nexus in Nigeria. Management of Environmental Quality: An International Journal, 31(1), 18-31. https://doi.org/10.1108/meq-02-2019-0050.

Dursun, G., and Ogunleye, G. (2016) Economic growth, employment and poverty reduction: The case of west African countries. American Journal of Economics. Vol. 6(1) : 50-60.

Fei, L. (2018) Situation, Problems and Governance Policies of Agriculture. IOP Conf. Series: Earth and Environmental Science 237.

Franić, R., \& Mikuš, O. (2013). Chapter 10 Transformations in Croatian Agriculture and Agricultural Policy: Challenges and Opportunities within the European Context. In Agriculture in Mediterranean Europe: Between Old and New Paradigms (pp. 233-261). Emerald Group Publishing Limited. https://doi.org/10.1108/s10571922(2013)0000019012

Food and Agriculture Organization of the United Nations. (2020). FAOSTAT [Data file]. Retrieved from http://www.fao.org/faostat/en/\#home

Harris, R., and Sollis, R. (2003). Applied Time Series Modelling and Forecasting. New York: Wiley.

Husnain, M. I. U., Subramanian, A., \& Haider, A. (2018). Robustness of geography as an instrument to assess impact of climate change on agriculture. International Journal of Climate Change Strategies and Management. https://doi.org/10.1108/ijccsm-03-20170049

Im, K. S., Pesaran, M. H., Shin, Y. (2003) Testing for Unit Roots in Heterogeneous Panels.J. Econ. $115,53-74$.

Kao, C., and Chaing, M. (2000) On the estimation and inference of a cointegrated regressionin panel data. Adv. Econ. 15, 179-222.

Levin, A., Lin, C.-F., and Chu, C.-S. J. (2002) Unit root tests in panel data: Asymptotic and finitesample properties. Journal of Econometrics 108: 1-24.

Li, S., Gong, Q., and Yang, S. (2019) Analysis of the Agricultural Economy and Agricultural Pollution Using the Decoupling Index in Chengdu, China. Int. J. Environ. Res. Public Health. Vol. 16: 1-11.

Liddle, B. (2012). The importance of energy quality in energy intensive manufacturing: Evidence from panel cointegration and panel FMOLS. Energy Economics, 34(6), 1819-1825. https://doi.org/10.1016/j.eneco.2012.07.013

Maddala, G. S., and Wu, S. (1999). A comparative study of unit root tests with panel data anda new simple test. Oxf. Bull. Econ. Stat. 61, 631-652.

Nasreen, S., and Anwar, S. (2014) Causal relationship between trade openness, economic growth and energy consumption: A panel data analysis of Asian countries. Vol. 69. 82-91. 
Payam., M. A., Tamat, S., and Fathin, F. S. (2018) Investigating the effect of financial innovations on the demand for money in Australia using DOLS and FMOLS and comparing their predictive powers. Regional Science Inquiry, Vol. X, (2) : 17-30.

Pingali, P. (2010). Agriculture Renaissance: Making "Agriculture for Development" Work in the 21st Century. In Rausser, G. C. Handbook of Agricultural Economics, 1st ed., Vol. 4, 38673894. Burlington: Academic Press, Elsevier BV. https://doi.org/10.1016/ S15740072(09)04014-6

Pedroni, P. (1999) Critical Values for Cointegration Tests in Heterogeneous Panels with Multiple Regressors. Oxford Bulletin of Economics and Statistics, 61, 653-70.

Pesaran, M. (2007) A simple panel unit root test in the presence of cross-sectiondependence. J. Appl. Econ. 22, 265-312.

Raza, S. A., Ali. Y., and Mehboob, F. (2012) Role of Agriculture in Economic Growth of Pakistan. International Research Journal of Finance and Economics. Vol. 83: 180-186.

Rasool, H., Malik, M. A., and Tarique. (2020) The curvilinear relationship between environmental pollution and economic growth Evidence from India. International Journal of Energy Sector Management: 1750-6220.

Pacheco, J., Ochoa-Moreno, W-S., Ordonez, J., and Montoya, L. I. (2018) Agricultural Diversification and Economic Growth in Ecuador. Sustainability. Vol. 10 : 1-17.

Ravallion, M., and Chen, S. (2004), "How have the world's poorest fared since the early 1980's", World Bank Research Observer, Vol. 19 No. 2, pp. 141-70

Regmi, P. P., and Weber, K. E. (2000) Problems to agricultural sustainability in developing countries and a potential solution: diversity. International Journal of Social Economics, Vol. 27 No. 7/8/9/10, 788-801.

Shairilizwan, T., and Remali, Y. (2014) Telecommunications Infrastructure Consequence to Economic Growth in Malaysia: Time Series Analysis. International Journal of Computer Trends and Technology. Volume 18 (5): 175- 179.

Shen, Z., Baležentis, T., Chen, X., \& Valdmanis, V. (2018). Green growth and structural change in Chinese agricultural sector during 1997-2014. China Economic Review, 51, 83-96. https://doi.org/10.1016/j.chieco.2018.04.014

Sun, B., Zhang, L., Yang, L., Zhang, F., Norse, D., \& Zhu, Z. (2012). Agricultural Non-Point Source Pollution in China: Causes and Mitigation Measures. AMBIO, 41(4), 370-379. https://doi.org/10.1007/s13280-012-0249-6.

The World Bank, World Development Indicators. (2020). Gross Domestic Product ASEAN, Atlas method [Data file]. Retrieved from https://data.worldbank.org/

Yip, P. S., Brooks, R., Do, H. X., and Nguyen, D. K. (2020) Dynamic Volatility Spillover Effects between Oil and Agricultural Products. International Review of Financial Analysis. Vol. 69. $1-34$.

Dao, Q. M. (2009). Poverty, income distribution, and agriculture in developing countries. Journal of Economic Studies, 36(2), 168-183. https://doi.org/10.1108/0144358091095505

Xiao, L., Liu, J., \& Ge, J. (2021). Dynamic game in agriculture and industry cross-sectoral water pollution governance in developing countries. Agricultural Water Management, 243, 106417. https://doi.org/10.1016/j.agwat.2020.106417

Zafeiriou, E., Mallidis, I., Galanopoulos, K., and Arabatzis, G. (2018), “Greenhouse gas emissions 
INTERNATIONAL JOURNAL OF ACADEMIC RESEARCH ECONOMICS AND MANAGEMENT SCIENCES Vol. 10, No. 3, 2021, E-ISSN: 2226-3624 @ 2021 HRMARS

and economic performance in EU agriculture: an empirical study in a Non-Linear framework", Sustainability, Vol. 10 No. 11, https://doi:org/10.3390/su10113837. 